\title{
DEVELOPMENTAL LEVEL OF BLACK FIRST-YEAR NURSING STUDENTS
}

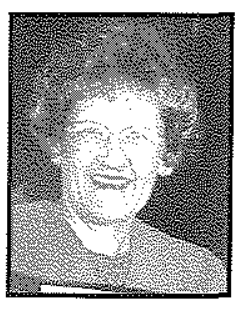

\section{Paula P du Rand}

Ph.D, Senior Lecturer, School of Nursing, Faculty of Health Sciences UOFS

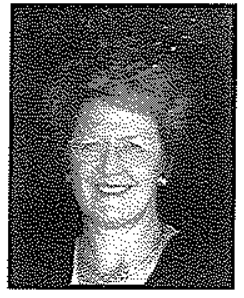

\section{Marlene J Viljoen}

D.Soc.Sc., Head, School of Nursing

Faculty of Health Sciences

UOFS

\section{SUMMARY}

Black first-year nursing students hailing from a historically disadvantaged educational situation may experience various problems at the university. It is therefore important to support these students. If, however, it should prove possible to determine the exact nature of the backlogs in their development, the lecturer would be able to offer meaningful support.

During this research the students' development was determined with the aid of the Student Development Task and Lifestyle Questionnaire at the beginning of the year and again at the end of the year. The questionnaire is based on Chickering's (1972) seven vectors model and was designed by Winston, Miller and Price (1979). The survey method was used and the aim was to determine the developmental level of the students and to adjust inputs to them accordingly. Feedback sessions were held with students and they were provided with a guide showing them how to stimulate their own development.

The students achieved higher than average scores for the task of establishing and clarifying purpose. Their level of development with regard to cultural participation was average. Unfortunately their developmental level regarding mature interpersonal relationships was below average. Students ought to benefit by the development of this subtask in order to enter into successful communication with patients/clients.

Once deficiencies in the student's developmental level have been pinpointed, meaningful support should be offered that would contribute to the student's development. Regular feedback to students is therefore important. The most important benefit of this questionnaire is that students acquire insight in their own level of development.

\section{OPSOMMING}

Swart eerstejaar verpleegkunde studente wat uit "n histories benadeelde onderrigsituasie kom, kan verskeie probleme op universiteit ervaar. Dit is dus belangrik om hierdie studente te ondersteun. Indien daar egter vasgestel kan word waar die leemtes in hul ontwikkeling gesetel is, kan die dosent sinvolle ondersteuning bied.

In hierdie navorsing is die studente se ontwikkeling aan die begin van die jaar en aan die einde van die jaar met behulp van die Student Ontwikkelings en Lewensstyl Vraelys bepaal. Die vraelys is gebaseer op Chickering (1972) se sewe vektore model en ontwerp deur Winston, Miller en Price (1979). Die opname metode is gebruik en die doelstelling was om die ontwikkelingsvlak van die studente te bepaal en daarvolgens insette aan studente te lewer. Terugvoer sessies is aan studente verskaf en ' $n$ gids is aan hulle oorhandig wat aksies aandui van hoe om ontwikkeling te stimuleer.

Studente het bo gemiddelde tellings in die vasstelling en verheldering van doelwitte taak behaal. Ten opsigte van kulturele deelname is die vlak van ontwikkeling gemiddeld. Ongelukkig is die vlak van ontwikkeling by volwasse interpersoonlike verhoudings ondergemiddeld. Studente behoort baat te vind by die ontwikkeling van hierdie subtaak sodat suksesvolle kommunikasie met pasiënte/kliënte aangeknoop kan word. Nadat leemtes in die student se ontwikkelingsvlak uitgewys is, behoort sinvolle ondersteuning gebied te word wat tot die student se ontwikkeling bydra. Gereelde tertigvoer aan studente is dus belangrik. Die belangrikste voordeel van hierdie vraelys is dat studente insig verwerf in hul eie vlak van ontwikkeling.

\section{INTRODUCTION}

The university environment provides an ideal setting for the development of first year nursing students, as the focus is on learning and development. However, lecturers are not always aware of the level of development of their students, nor of factors that may influence development. In the case of nursing students it appears to be necessary to focus not only on intellectual needs, but also on the student as a total person and to pay attention to their physical, psychological and mental development.

\section{BACKGROUND TO THE STUDY}

With the change of the student culture in the School of Nursing from a traditional white Afrikaans-speaking to a multicultural student community, first-year students hailing from historically disadvantaged educational situations in particular experienced various problems. In order to cope with these problems a support programme was developed. This largely consisted of small-group work (tutorials) offered outside the context 
of scheduled lectures. The focus largely fell on reading, writing and language skills. Students were also supported in the clinical practice. For the planning of additional support actions it however, proved necessary to determine the students' developmental level before and after the programme. As the Student Development Task and Lifestyle Questionnaire (SDLQ) had already been used in several studies, it was also implemented in this research.

\section{PROBLEMSTATEMENT}

Black students do not only have educational deficits, they also experience culture shock when they enter the university (Luthuli, Masiea \& Zuma, 1992:30, 33; Ferreira, 1995:154). The language problem, added to stressful situations they may encounter in the practice situation, make the adjustment even more difficult. This may result in students, especially at the beginning of their first year, lagging behind with their studies if the necessary support is not provided. Generally speaking the backlog is not made up and the result is that students lose heart, abandon their studies or fail. Apart from the financial implications of poor academic achievement, failure can have a detrimental effect on the self-concept of students.

It is clear from the foregoing discussion that it is essential to provide students with support. If effective change and growth are objectives it will be necessary to determine their developmental level in order to pinpoint deficiencies.

\section{REVIEW OF THE LITERATURE}

An instrument designed by Winston, Miller and Price (1979) is available to measure psychosocial development as it is influenced by higher education. The measuring instrument is based on Chickering's (1969) theory of the psychosocial development of students. This theory is regarded as an important exposition, which is of particular value in offering support to students (Winston, 1990:108; Stonewater, 1987:365; Taub \& McEwen, 1992:439).

In order to obtain a better understanding of Chickering's (1969) theory it will be briefly discussed as set out in Chickering and Reissler (1993:45-52).

\section{Chickering's seven vector model}

In 1969 Chickering obtained very important information about the nature and direction of the development of students by means of longitudinal studies at 13 small American universities. This model may serve as a basis for educational planning and centres around the establishment of a personal identity. Chickering and Reissler (1993) differentiate seven important areas of development in students. These areas are synonymous with a variety of growth patterns, developmental tasks, developmental phases and needs and problem areas of the student development process as identified by other researchers. The model refers to vectors because a vector indicates direction as well as scope. The seven vectors are:

- The development of competencies or skills (intellectual, physical or hand, social and interpersonal)

- Control over emotions (becoming aware, learning to experience and to control)

- Developing autonomy (striving towards independence and becoming aware of interdependence with others)

- Free interpersonal relationships

- Establishing an identity

- Clarifying purpose (planning a meaningful and structured life plan)

- Developing integrity (personal valid and consistent value system to serve as a frame of reference for behaviour)

This model serves as a useful framework for the areas of development the student needs to master and according to which educational objectives can be planned. Chickering does not assume that all students undergo change in all seven vectors. Change is far easier for some students than for others and is directly related to environmental impact (Chickering \& Reissler, 1993:43).

\section{AIM OF THE STUDY}

To ascertain the developmental level of students and to provide them with input accordingly.

\section{Objectives}

To

- ascertain the developmental level of students at the beginning and end of the year;

- identify deficiencies in the development of students; and

- provide students with feedback.

\section{RESEARCH METHODOLOGY}

The survey method was used and the research objective was to explore and describe. This research is contextually bound to the context of black nursing students at the University of the Orange Free State. All the black first year students of 1997 , that is, 33 , were included in the sample.

\section{ETHICAL CONSIDERATIONS}

Students were informed in such a way that they understood the aim of the research and the research method. Written consent to participation was given. 
In this research anonymity and confidentiality were ensured by the fact that the names of the participants would not be made public. Privacy was ensured by the fact that feedback was provided in privacy and that every participant was aware of his/her freedom to provide or withhold information.

\section{DATA COLLECTION INSTRUMENT (SDLQ)}

It is difficult to compile instruments that measure the psychosocial development of students as this development is influenced by higher education. However, the SDLQ has been successfully applied in a number of studies (Stonewater, Daniels \& Heischmidt, 1986:70-74; Winston, 1990:108-120; Schultheiss \& Blustein, 1994:248-255). The questionnaire comprises developmental tasks, subtasks and scales and was compiled by Winston, Miller and Price (1979).

A developmental task is defined as an interrelated set of behaviours and attitudes specified in a particular context at a particular time and that should be exhibited.

A subtask is a more specific component or aspect of a greater developmental task.

A scale is the measurement of the degree to which students report certain behavioural characteristics, attitudes and feelings that are not directly influenced by participation in the academic environment.

The SDLQ consists of three developmental tasks, two of which are subdivided by subtasks, and three scales. A brief description of the tasks, subtasks and scales follows.

The questionnaire is portrayed schematically in Figure 1.

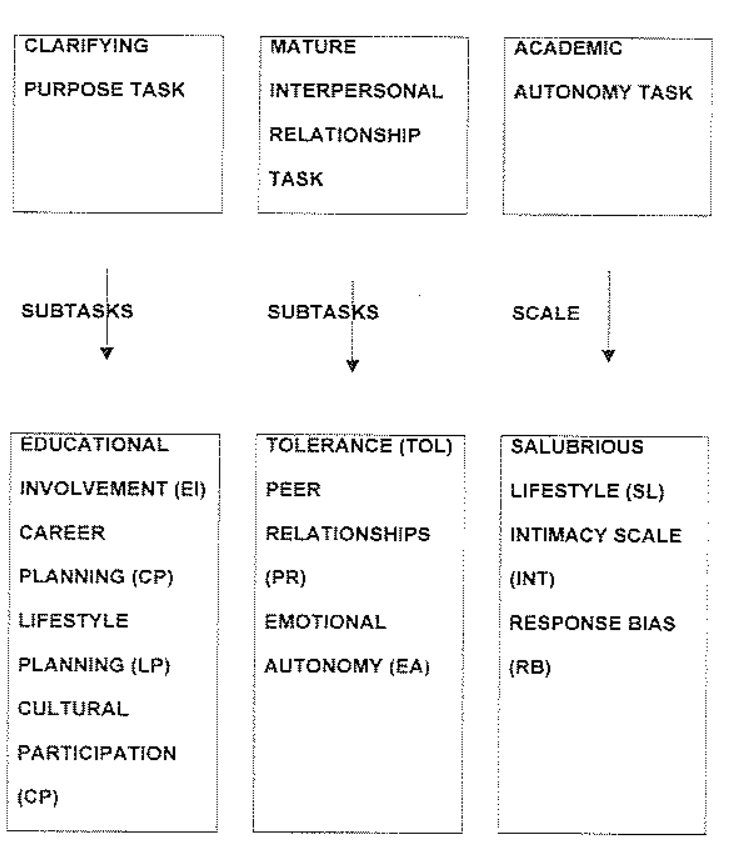

FIGURE 1: Schematic portrayal of the SDLQ questionnaire

\section{Establishing and Clarifying Purpose Task (PUR)}

This developmental task is refined by five subtasks:

\section{Educational involvement (IE) (16 items)}

This measures the extent to which students develop well-defined objectives and well thought out educational objectives and plans and whether they are active, self-directed learners.

\section{Career planning (CP) (19 items)}

The extent to which students have synthesised knowledge about themselves and about work in order to make appropriate plans for the future, are measured here. They must make an emotional commitment and take steps to realise their career objectives.

\section{Lifestyle Planning (LP) (11 items)}

The extent to which students have established personal direction in their lives is determined. This includes future plans taking into account personal, ethical and religious values as well as further objectives with regard to their family, profession and training.

\section{Life Management (LM) (16 items)}

This measures the degree to which students structure their lives and manipulate their environment in a manner that allows them to satisfy their daily needs. It also measures personal responsibility, the management of personal finance and whether academic obligations are met.

\section{Cultural Participation (CP) (6 items)}

This assesses students' interest in cultural aspects and the degree to which they take part in cultural activities.

\section{Developing Mature Interpersonal Relationships Task (MIR)}

This questionnaire consists of three subtasks:

\section{Peer relationships (PR) 13 items}

This measures the extent to which students develop relationships with their peer group and includes characteristics such as independence, honesty and trust. It also measures the degree of individual differences between friends - whether they feel forced to conform to the norms of the group or to air their opinion.

\section{Tolerance (TOL) (9 items)}

This measures the degree to which students enter into relationships with members of different cultures, races and backgrounds. It also measures the extent to which they show respect and acceptance.

\section{Emotional Autonomy (EA) (8 items)}

The degree to which students need the reassurance and approval of others is determined. The scale measures 
the extent of independence from their parents regarding decision-making.

\section{Academic Autonomy Task (AA)}

Composed of 10 items. This task measures students' capacity to cope with ambiguity and to monitor and control their own behaviour in order to achieve their educational objectives.

\section{Salubrious Lifestyle (SL) Scale}

This scale is made up of 8 items and measures the degree to which a student's life is stable. It also measures the extent to which good health and welfare practices are promoted, such as eating nutritious meals and whether effective stress management techniques are used.

\section{Intimacy (INT) Scale}

The scale consists of 19 items and is only completed by students who report that they are involved in a relationship. It measures the degree to which a student has established an intimate or romantic relationship with someone of the opposite sex, based on mutual respect, honesty, acceptance, care and trust.

\section{Response Bias (RB)}

This consists of 5 items aimed at identifying students who tried to put up a front in the questionnaire and those who were careless in filling it out (Winston, 1990:109110).

\section{Validity and reliability of the questionnaire}

Test-retest was used to determine temporal stability. (An indicator of how a subject's performance on one item on the instrument relates to all other items). The Cronbach alpha was used to determine the degree of internal consistency.

The short-term test-retest coefficient varied between 0.70 and 0.87 and the long-term coefficiency of an academic year varied between 0.53 and 0.80 . The Cronbach alpha for all tasks and scales was 0.70 and higher. According to the literature this degree of reliability and validity is satisfactory (Winston, 1990:110-113; Schultheiss \& Blustein, 1994:249).

Construct validity was proved by the theoretical deduction of the extent of the items as well as the correlating studies that have been performed and that proved a significant correlation with the measurement of study habits $(r=0.29)$, career planning $(r=0.70)$ career exploration $(\mathrm{r}=0.49)$ and family independence $(\mathrm{r}$ $=0.44$ ) (Winston, 1990:110-113; Schultheiss \& Blustein, 1994:249).

The questionnaire was also standardised for black Americans, which enhances its feasibility for application in this study (Winston \& Miller, 1987:4).

\section{Completion of the questionnaire and feedback sessions}

The aim of the questionnaire was explained to the black students and voluntary participation was requested. All the students (33) agreed to complete the questionnaire which the researcher explained to them after providing each student with a questionnaire and an answer paper. The questionnaire was filled out in class and took between 45 and 60 minutes to complete.

The results of the questionnaire were entered on profile sheets and handed to the students. During the orientation period all available resources that students may use to stimulate their development were pointed out to them.

At the end of the year the students were again asked to complete the questionnaire and these results were also entered on their profile sheets. This enabled them to ascertain their development over the year. An average class percentage was obtained and the students could compare their own with it.

Feedback sessions were held with the students to discuss the results of the survey and activities they could perform to eliminate deficiencies in their development. At the request of the students these sessions were held at the beginning of 1997.

Ten students were present at each feedback session and a profile sheet was handed to each one. The meaning of each subtask was once again explained and activities were suggested to stimulate their development in specific subtasks. A guide was compiled and distributed among them.

Good interaction among the students took place at these sessions. They also suggested a variety of activities to aid their development.

\section{DATA ANALYSIS}

The questionnaires were analysed by the researcher with the aid of a key supplied with the original. An average raw score was calculated for each area. By using the tables provided by the author of the questionnaire, $\mathrm{T}$-scores were provided for each raw score. The $\mathrm{T}$-scores are regarded as an indication of development in the different areas. A higher T-score indicates better achievement. When standardising the questionnaires in previous studies, an average score of 50 was recorded (Winston \& Miller, 1987:1).

\section{Establishing and Clarifying Purpose Task (PUR)}

The five subtasks of the PUR are discussed under this heading, i.e. educational involvement (EI), career planning (CP), lifestyle planning (LP), life 

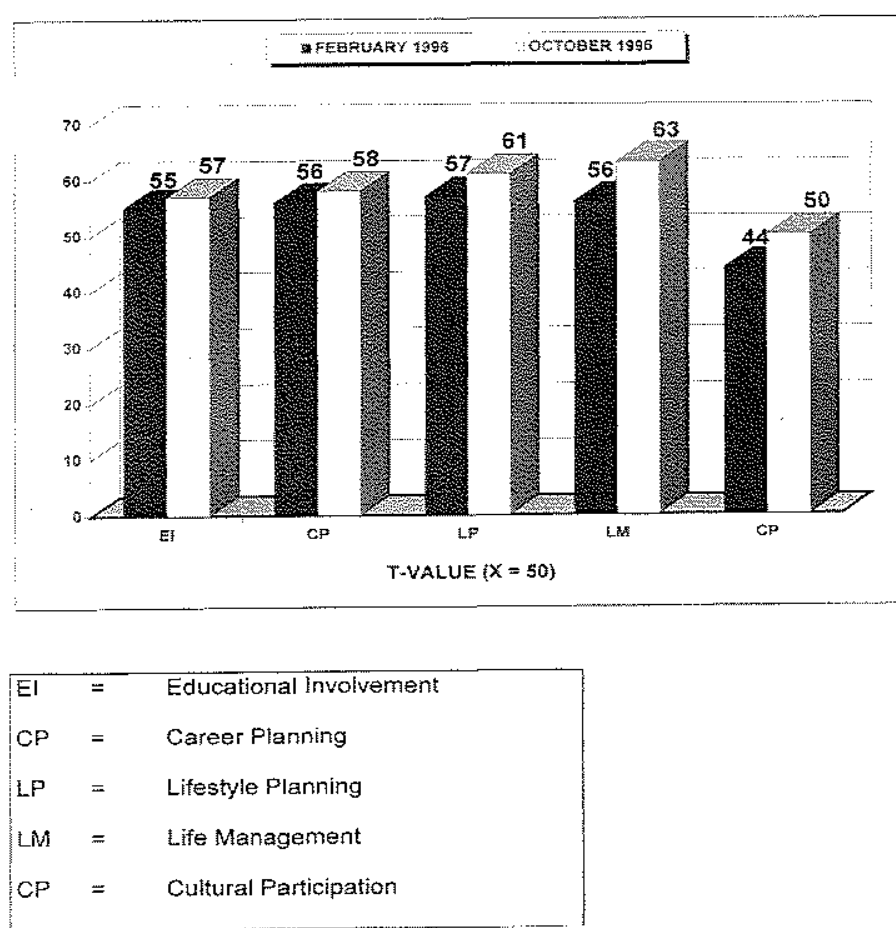

FIGURE 2: Establishing and Clarifying Purpose Task in February 1996 \& October 1996

management (LM) and cultural participation (CP). These are represented in Figure 2.

\section{Educational Involvement(EI)}

In Figure 2 the average score of educational involvement is represented as 55 in February and 57 in October. Students were 5 above average in February and 7 above in October. By educational involvement is meant that students have well defined educational objectives and plans and are actively involved in the academic life.

\section{Career Planning (CP)}

In career planning the students also tested above 50 , that is, 56 in February with a growth of 2 to 58 in October (Figure 2). This subtask should score considerably higher for nursing students since they had already selected their career at the beginning of the year when they registered for the nursing course, in contrast with other students who in some cases do not choose a career before they have obtained their degree. It must be remembered, however, that these were first year students and that the end of their course lay far in the future. There is, therefore, sufficient time available to grow in this subtask.

\section{Lifestyle Planning (LP)}

Students with high scores in this subtask demonstrate consciousness of their attitudes and beliefs and can analyse their own behaviour. They therefore have personal direction and clear plans for the future. As indicated in Figure 2 the students obtained an average of 56 in February. Clear growth of 7 to 63 was achieved at the end of the year. Taking into account the fact that the students had a further three years to develop in this subtask, this growth is significant.

\section{Life Management (LM)}

Life management measures the degree to which students structure their lives and manipulate their environment in a manner that allows them to meet their daily needs. Growth is again exhibited in Figure 2, from 56 to 63 , which indicates that personal responsibility in managing personal finance and academic commitments is fulfilled.

\section{Cultural Participation (CP)}

Especially at the beginning of the year the score of 44 in Figure 2 shows clearly that students scored under average in this subtask. However, development up to 50 had taken place by the end of the year. For successful integration in cultural activities more attention must be given to this aspect as students are expected to nurse patients of all cultural groups.

\section{Development of Mature Interpersonal Relationship Task (MIR)}

This task consists of three subtasks, namely tolerance, peer relationships and emotional autonomy. They are represented in Figure 3.

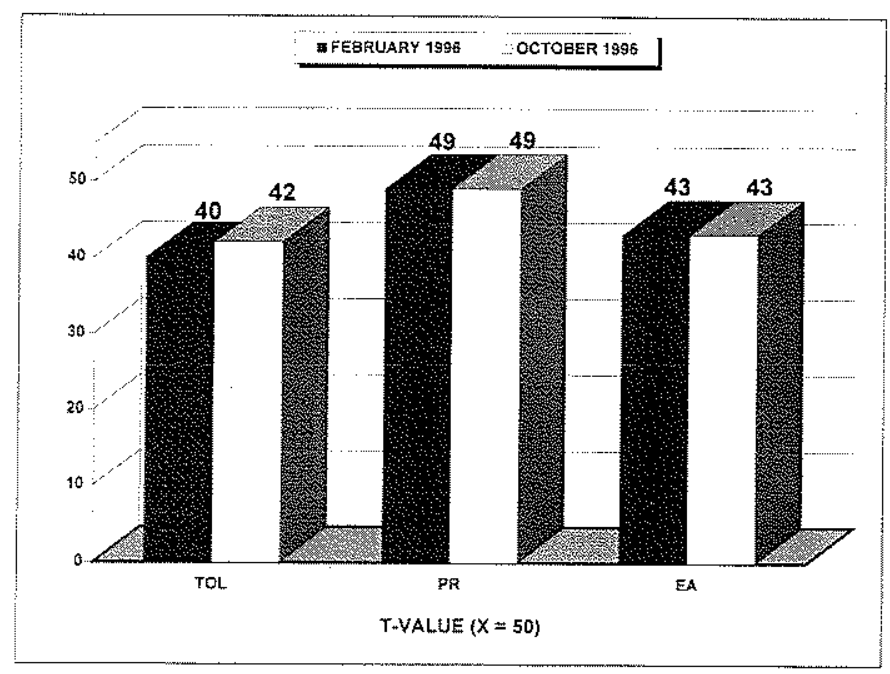

$\begin{aligned} \text { TOE } & =\text { Tolerance } \\ \mathrm{PR} & =\text { Peer Relationships } \\ \mathrm{EA} & =\text { Emotional Autonomy }\end{aligned}$

FIGURE 3: Development of Mature Interpersonal Relationship Task in February 1996 and October 1996

\section{Tolerance (TOL)}

Students scored 40 in February and 42 in October in this subtask as shown in Figure 3. One reason for these low scores may be related to the students' poor language ability. They were also exposed to an environment that differed hugely from their background. Due to parallel medium teaching the black students were not much exposed to white students as most of the latter were Afrikaans-speaking and were therefore separated from black students in the classroom. Spontaneous participation was, therefore, not satisfactory. 


\section{Peer Relationships (PR)}

No growth took place in this subtask as students obtained an average score of 49 at the beginning as well as at the end of the year as indicated in Figure 3.

\section{Emotional Autonomy (EA)}

A need was identified here as students obtained an average of only 43 in February and there was no growth by the end of the year, as shown in Figure 3. In view of the fact that the average age of the students was 26 years this subtask should have reflected a higher score. However, Parham and Helms (1985:143-147) found that black students have low self-esteem when they enter a mainly white university from a black school background. This may have influenced the emotional autonomy of these students.

As reflected in Figure 3 the developmental level of the students regarding the interpersonal relationship task was generally below the average score of 50 . Since interpersonal relationships play such an important role in the nursing profession students should achieve higher scores in this subtask.

\section{Academic Autonomy (AA)}

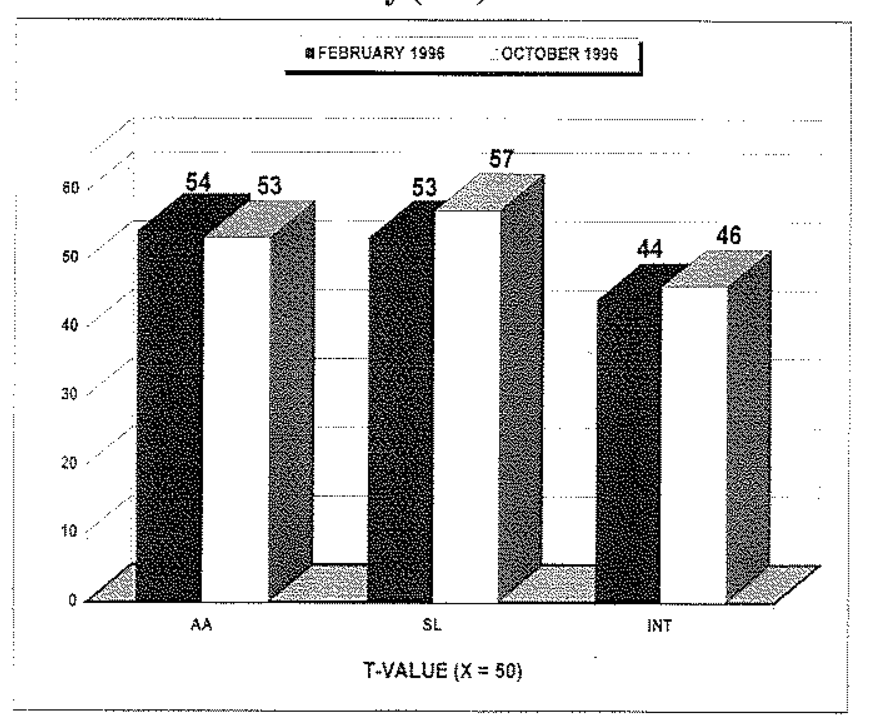

$\mathrm{AA}=$ Academic Autonomy
$\mathrm{SL}=$ Salubrious Lifestyle
$\mathrm{INT}=$ Intimacy Scale

FIGURE 4: Academic Autonomy Salubrious Lifestyle Intimacy Scale of students in February 1996 and October 1996

Figure 4 shows that students obtained 54 at the beginning of the year but that they fell to 53 at the end of the year. This may be attributed to the higher academic load they experienced in the second semester. According to Entwhistle (1990:65) an overloaded curriculum and too high a workload may result in a feeling of inadequacy. When the second questionnaire was completed in October the students may have felt that they had been unable to achieve their educational objectives.

\section{Salubrious Lifestyle (SL)}

Students obtained an average of 53 in February and developed to 57 by October. It appears that they maintained a healthy lifestyle in spite of a taxing practical component. This is essential in nursing, as nurses cannot give effective health education if they do not practise a healthy lifestyle themselves.

\section{Intimacy Scale (IS)}

Only students who were involved in a romantic relationship completed this scale. Only $3(9 \%)$ were not involved in such a relationship. The extent to which a student establishes a relationship with someone else that is based on mutual respect, honesty, acceptance, care and trust, is measured by this scale. Figure 4 shows that students scored below average both at the beginning and the end of the year. This shows that they had not yet arrived at this level of development as indicated by the following quotation:

"Intimacy involves the capacity to love and care for another and to be loved and cared for by another, as well as testing one's ability and desire to make longterm commitments" (Winston \& Miller, 1987:4).

\section{CONCLUSION}

Taking into account the fact that an average score of 50 was recorded in previous studies, the students did not achieve high scores. However, above average scores were obtained in the task of establishing and clarifying purpose and growth took place during the year. Unfortunately the level of development in mature interpersonal relationships was below average and no growth took place over the year. Although students tested above average in the academic autonomy task at the beginning of the year, there was a drop at the end of the year.

The most important benefit of this questionnaire was the insight the students gained in their own development and, in collaboration with the lecturer, their planning of activities to stimulate their development.

\section{RECOMMENDATIONS}

It is of the utmost importance for students to understand the aim of the questionnaire and to show insight in the fact that all behaviour described in it is "normal". A student cannot be classified as abnormal regardless of how she responds in the questionnaire. Students must realise that if they have a deficit in one area development can take place at a later stage.

After analysing the questionnaire the lecturer should work through it with each individual student and should suggest activities that may be carried out.

Students must be encouraged to become actively 
involved in academic life. They should be encouraged to set their own educational objectives and plans.

With regard to life management, aspects such as time management, study methods and the avoidance of procrastination should be emphasised in a development programme.

For successful integration in cultural activities it is essential to pay more attention to this aspect because students are expected to nurse patients of all cultural groups. Black and white students as well as lecturers should make contact outside the classroom at the social level (Wettles, Thoeny \& Gosman, 1986:289-293).

More time should be spent on the development of the mature interpersonal relationship task. The poor language ability of the students should be addressed. The inclusion of English Special as a credit-bearing course in the nursing curriculum should be considered. Such a course should be offered in context and be appropriate for nursing students. The need to integrate communication skills, assertiveness training and conflict management in the course of first year students cannot be overemphasised.

Every student should work through the guide setting out actions to develop specific areas. Regular feedback sessions between students and lecturer should take place in which deficits are pointed out and development is continually stimulated.

\section{SUMMARY}

As mentioned in the problem statement it appears to be necessary to offer support to black students in particular. The questionnaire seems to be of value in supporting students in order to highlight deficiencies. The developmental level of students was determined at the beginning and end of the year. In general students did not register high scores and in some aspects such as mature interpersonal relationships their achievement was below average. Regarding development Winston and Miller (1987:2) take the view that:

"People develop at different rates and at uneven intervals. Students lagging in certain areas of development therefore will probably acquire these skills at a later stage in their lives."

\section{BIBLIOGRAPHY}

CHICKERING, AW \& REISSER, L 1993: Education and identity; 2nd edition. San Francisco: Jossey Bass Publishers.

CHICKERING, AW 1969: Education and identity. San Francisco: Jossey-Bass Publishers.

CHICKERING, AW 1972: Education and identity. San

Francisco: Jossey-Bass.
ENTWISTLE, NE 1990: Teaching and quality of learning in higher education. (In: Entwistle, NE (ed.) 1990: The experience of learning. Edinburg: Scottish Academic Press Ltd.)

FERREIRA, JG 1995: Transition from school to university. South-African Journal of Higher Education, 9(1):154-158.

LUTHULI, ND; MASIEA, SE \& ZUMA, LC 1992: The hurdles faced by black students. Nursing RSA Verpleging, 7(2):30-33.

PARHAM, TA \& HELMS, JE 1985: Attitudes of racial identity and self-esteem of black students: An exploratory investigation. Journal of College Student Personnel, 26:143-147.

SCHULTHEISS, DEP \& BLUSTEIN, DL 1994: Role of adolescent-parent relationship in college student development and adjustment. Journal of Counseling Psychology, 41(2):248-255.

STONEWATER, BB 1987: The second edition of the student developmental task inventory and sex differences: A factor analysis. Journal of College Student Personnel, 28:365-369.

STONEWATER, J; DANIELS, MH \& HEISCHMIDT, K 1986: The reliability and validity of the student development. Task inventory - 2: Pilot studies. Journal of College Student Personnel, 27:70-74.

TAUB, DJ \& McEWEN, MK 1992: The relationship of racial identity attitudes to autonomy and mature interpersonal relationships in black and white undergraduate women. Journal of College Student Development, 33(5):439-446.

WETTLES, R; THOENY, G \& GOSMAN, P 1986: Potential uses of non-cognitive measurement in education. Journal of Educational Psychology, 71:281-292.

WINSTON, R 1990: The student developmental task and lifestyle inventory: An approach to measuring students' psychosocial development. Journal of College Student Development, March 1990, 31:108120 .

WINSTON, RB; MILLER, TK \& PRICE, JS 1979: Student developmental task inventory. Athens GA: Student Development Associates. 